\title{
Characterization of two newly isolated Staphylococcus aureus bacteriophages from Japan belonging to the genus Silviavirus
}

\author{
Naoya Kitamura $^{1}$ (D) Eri Sasabe $^{1} \cdot$ Shigenobu Matsuzaki $^{2,3} \cdot$ Masanori Daibata $^{2} \cdot$ Tetsuya Yamamoto $^{1}$
}

Received: 6 January 2020 / Accepted: 24 June 2020 / Published online: 3 August 2020

(c) The Author(s) 2020

\begin{abstract}
Two Staphylococcus aureus bacteriophages, KSAP7 and KSAP11, were isolated from sewage and characterized. Based on morphology and DNA sequences, they were assigned to the genus Silviavirus, subfamily Twortvirinae, family Herelleviridae, whose members are hypothesized to be suitable for bacteriophage therapy. The KSAP7 and KSAP11 genomes were 137,950 and 138,307 bp in size, respectively. Although their DNA sequences were almost identical, evidence of site-specific DNA rearrangements was found in two regions. Changes in the number of PIEPEK amino acid sequence repeats encoded by orf10 and the insertion/deletion of a 541-bp sequence that includes a possible tail-related gene were identified.
\end{abstract}

Increased resistance of pathogenic bacteria to antibacterial agents has prompted the development of alternatives and/or supplements to current antibacterial therapies. One of the most potent antibiotic-independent alternatives is bacteriophage (phage) therapy [1]. In phage therapy, phages (viruses specific for bacteria) or phage products such as endolysin and depolymerase [2-4] function as antibacterial agents. A large number of phages have been isolated and characterized for the purpose of developing phage therapies. Virulent phages, which do not exhibit a lysogenic cycle, are generally considered more suitable than lysogenic phages due to the low likelihood of superinfection exclusion, in which lysogens act against the same type of phage, and of the transfer of pathogenic genes [5].

Handling Editor: Johannes Wittmann.

Electronic supplementary material The online version of this article (https://doi.org/10.1007/s00705-020-04749-6) contains supplementary material, which is available to authorized users.

Naoya Kitamura

nkitamura@kochi-u.ac.jp

1 Department of Oral and Maxillofacial Surgery, Kochi Medical School, Kochi University, Nankoku, Kochi 783-8505, Japan

2 Department of Microbiology and Infection, Kochi Medical School, Kochi University, Nankoku, Kochi 783-8505, Japan

3 Present Address: Department of Medical Laboratory Science, Faculty of Health Sciences, Kochi Gakuen University, Kochi, Kochi 780-0955, Japan
Most of the therapeutic candidate phages reported to date have been assigned to the order Caudovirales (namely tailed phages) [6, 7]. Phages with a tail and contractile sheath, which have been traditionally assigned to the family Myoviridae, have now been reorganized into three families based on DNA sequence: Myoviridae, Herelleviridae, and Ackermannviridae [8].

In this study, we isolated and characterized two previously undescribed Staphylococcus aureus phages, KSAP7 and KSAP11, belonging to the genus Silviavirus, subfamily Twortvirinae, family Herelleviridae, whose members are reportedly suitable for phage therapy [9]. Comparison of the DNA sequences of the phages KSAP7 and KSAP11 suggested that there are at least two regions in the phage genome where site-specific DNA rearrangement occurs.

The bacterial strains used in this study are shown in Table S1. Reagents and media were purchased from Nacalia Tesque (Kyoto, Japan), FUJIFILM Wako Pure Chemical Corporation (Osaka, Japan), Sigma-Aldrich Japan (Tokyo, Japan), and BD Japan (Tokyo, Japan).

Phages were isolated from a sewage plant in the city of Kochi, Japan, essentially according to a previously reported method [10, 11]. Briefly, after removing debris from sample water using a loose filter (no. 514A, Advantec, Tokyo, Japan), phages were concentrated by addition of $10 \%$ polyethylene glycol (PEG) 6000 and $0.5 \mathrm{M} \mathrm{NaCl}$ (approximate final concentration) with successive centrifugation at 10,000 $\times g$ for $5-10$ min at $4{ }^{\circ} \mathrm{C}$. The pellet was resuspended in tryptic soy broth supplemented with $20 \mathrm{mM} \mathrm{MgCl}_{2}$ (TSBM) and then filtered using a $0.45-\mu \mathrm{m}$-pore-size filter. The filtrate 
was inoculated with $S$. aureus strain IID975 and incubated overnight at $37{ }^{\circ} \mathrm{C}$ to enrich for phages. The culture was centrifuged at $10,000 \times g$ for $5-10 \mathrm{~min}$ at $4{ }^{\circ} \mathrm{C}$, and the supernatant was filtered. Phages were isolated by three successive single-plaque isolations on S. aureus IID975, using the double-layer method with TSBM-agar plates (upper layer, $0.5 \%$ agarose; lower layer, $1.5 \%$ agarose).

The host range was examined by streak testing on bacterial lawns of each strain to assess the plaque-forming ability of the phages. Briefly, $10 \mu \mathrm{l}$ of phage suspension was streaked using a disposable plastic loop onto the solidified upper layer with each host, and plaque formation was assessed after incubation for approximately $15 \mathrm{~h}$ at $37^{\circ} \mathrm{C}$.

Phages were amplified and purified as described previously for electron microscopic observation and DNA extraction [10, 11]. Briefly, phages were amplified using S. aureus strain IID975 as the host in $200-250 \mathrm{ml}$ of TSBM liquid medium at $37^{\circ} \mathrm{C}$. After centrifugation of the culture at $10,000 \times g$ for $5-10 \mathrm{~min}$ at $4{ }^{\circ} \mathrm{C}, 10 \%$ PEG 6000 and $0.5 \mathrm{M} \mathrm{NaCl}$ (approximate final concentration) were added to the supernatant, which was centrifuged at $10,000 \times g$ for $20 \mathrm{~min}$ at $4{ }^{\circ} \mathrm{C}$. The pellet was resuspended in TM (10 mM Tris- $\mathrm{HCl}, 5 \mathrm{mM} \mathrm{MgCl}$ [pH 7.2]) containing $100 \mu \mathrm{g}$ of DNase I and $100 \mu \mathrm{g}$ of RNase A per $\mathrm{ml}$ and incubated for $30 \mathrm{~min}$ at $37^{\circ} \mathrm{C}$. The phages were overlaid on a discontinuous $\mathrm{CsCl}$ density gradient ( $\rho$ [specific weight $]=1.3,1.5$, and 1.7) and then ultracentrifuged at $100,000 \times g$ for $60 \mathrm{~min}$ at $4{ }^{\circ} \mathrm{C}$ using S80AT3 and S100AT4 rotors and a GX series Himac CS 100GX micro-ultracentrifuge (Hitachi Ltd., Tokyo, Japan). The phage band was recovered and dialyzed against $1000 \mathrm{ml}$ of AAS (100 mM ammonium acetate, $10 \mathrm{mM} \mathrm{NaCl}, 1$ $\mathrm{mM} \mathrm{MgCl} 2$, and $1 \mathrm{mM} \mathrm{CaCl}_{2}$, [pH 7.2]) for $60 \mathrm{~min}$ at $4{ }^{\circ} \mathrm{C}$ (molecular weight cutoff, $10 \mathrm{kDa}$ ). The sample of phages was then placed on a mesh grid (Excel support film, Nisshin EM, Tokyo, Japan), negative-stained with $2 \%$ uranyl acetate, and examined by electron microscopy (JEM-1400 Plus, JEOL, Tokyo, Japan). The remaining dialyzed suspension was ultracentrifuged again at 100,000 $\times g$ for $60 \mathrm{~min}$ at $4{ }^{\circ} \mathrm{C}$. Phage DNA was prepared from the pellet by phenol extraction after solubilization in TE containing $1 \%$ SDS, followed by ethanol precipitation. The DNA samples were subjected to Illumina sequencing by Eurofins Genomics (Tokyo, Japan). Gapped regions were filled using the primer-walking method with a Model 3130 Genetic Analyzer (Applied Biosystems, Foster City, CA, USA) after sequencing reactions using an ABI Big Dye Terminator 1.1 Cycle Sequencing Kit (Applied Biosystems). The sequence around the orf 10 gene in the KSAP11 genome was determined after cloning of the PCR product encoding this region. The complete DNA sequences of KSAP7 and KSAP11 were submitted to the DDBJ/ EMBL/GenBank database under the accession numbers LC492751 and LC492752, respectively.

Host range of the phages was examined using 30 strains, including both MSSA and MRSA strains (Table S1). Although KSAP11 formed plaques on all of the strains examined (30/30), KSAP7 did not form plaques on two strains, MR7 and MR12 (28/30), suggesting that some aspect of the infection process, such as adsorption, differs between KSAP7 and KSAP11.

KSAP7 and KSAP11 were morphologically similar (Fig. 1). KSAP7 had an icosahedral head $(108.3 \pm 4.3 \mathrm{~nm}$ [mean and standard deviation]) and tail with a contractile sheath (length $234.8 \pm 1.4 \mathrm{~nm}$; width, $19.2 \pm 1.7 \mathrm{~nm}$ ). Similarly, KSAP11 also had an icosahedral head (103.0 \pm $1.5 \mathrm{~nm}$ ) and tail with a contractile sheath (length $234.6 \pm$ $5.4 \mathrm{~nm}$; width, $20.3 \pm 0.7 \mathrm{~nm}$ ). Means and standard deviations were determined from five and three samples of KSAP7 and KSAP11, respectively, using images at $\times 80,000$ magnification.

The KSAP7 and KSAP11 genomes were 137,950 bp and $138,307 \mathrm{bp}$ in size, respectively. A BLASTn search (https ://blast.ncbi.nlm.nih.gov/Blast.cgi) indicated that these phages were closely related to members of the genus Silviavirus, namely SA11 [12], Remus and Romulus [9], Stau2 [13], StAP1 [14], and фMR003 [15]. Phylogenetic analysis using MEGA7 software [16] also indicated that KSAP7 and KSAP11 were closely related to these phages, particularly Remus and Romulus (Fig. S1). Based on these morphologic
Fig. 1 Electron micrographs of phages KSAP7 and KSAP11. Bar, $100 \mathrm{~nm}$. Photographs were taken at $\times 80,000$ magnification
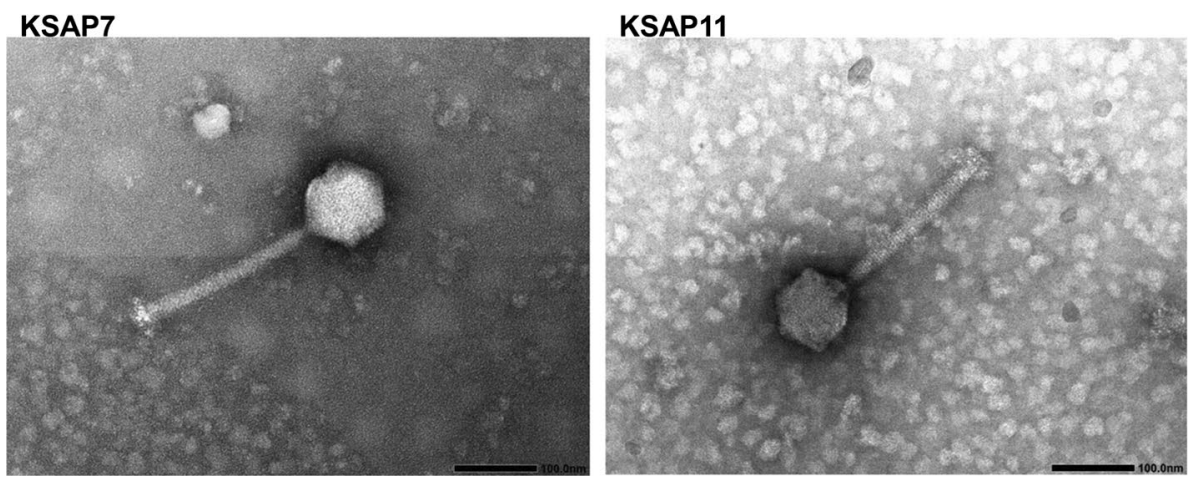
and genetic data, phages KSAP7 and KSAP11 were tentatively assigned to genus Silviavirus, subfamily Twortvirinae, family Herelleviridae.

The KSAP7 and KSAP11 genomes appeared to contain 187 and 188 predicted genes, respectively. In this paper, genes and gene products are designated as orf and ORF, respectively. In the genomes of both phages, the regions spanning orf1 to orf142 (ca. 113,000 bp) and orf185 to orf187 (ca. 1,000 bp) were oriented in the same direction. In contrast, the region spanning orf143 to orf184 (ca. 23,000 bp) was oriented in the reverse direction relative to the remaining orfs (Fig. 1a). A BLASTp search of the ORFs did not reveal any genes related to lysogeny, suggesting that these are virulent phages. In addition, no genes related to toxins such as hemolysin, enterotoxin, toxic shock syndrome toxin 1, Panton-Valentine leucocidin, and exfoliative toxin, which are known to be present in the S. aureus genome and/ or in those of its prophages, or drug resistance were found.

In Remus and Romulus phages, genes encoding the large terminase subunit, portal protein, helicase, ribonucleoside reductase subunit, DNA-repair protein, and DNA-polymerase I reportedly split into several parts and/or include a group I intron encoding a homing nuclease gene $[9,17]$. The corresponding genes in the KSAP7 and KSAP11 genomes for the large terminase subunit (orfl to orf6), portal protein (orf12 to orf15), helicase (orf47 to orf48), ribonucleoside reductase subunit (orf68 to orf72), and DNA-repair protein (orf83 to orf85) appeared to be arranged in a manner similar to that reported for the Remus and Romulus genomes. It was predicted that mRNA splicing and/or fusion of the synthesized peptides would occur in the synthesis of each protein.

Although a putative group I intron including the I-RoReV endonuclease gene was identified between the two segmented DNA polymerase I orfs in the genome of Remus and Romulus phages, no endonuclease gene sequence was found in either the KSAP7 or KSAP11 genome (orf77 and orf78). However, the intein amino acid sequence region, which is removed after translation, in the DNA polymerase I (ORF75) of Remus and Romulus was also predicted to be present in the DNA polymerase I (ORF78) of KSAP7 and KSAP11 [9]. The presence and type of homing-endonuclease gene and presence of an intein-encoding sequence in this genome region of silviaviruses varied considerably from strain to strain (data not shown).

The DNA sequences of phages KSAP7 and KSAP11 were identical except in two regions (orf10 and orf88.1), which was confirmed by comparison of the two complete nucleotide sequences using BLASTn. Since these phages were isolated from the same sewage sample, they are predicted to have diverged from a common ancestor very recently.

Orflo encodes a protein of 286 and 226 amino acid residues in KSAP7 and KSAP11, respectively. The amino acid sequence of the $\mathrm{N}$-terminal region (amino acid residues 1-199) encoded by orf10 was identical in KSAP7 and KSAP11. Furthermore, the C-terminal region (amino acid residues 260-286) encoded by KSAP7 orf10 was identical to that (amino acid residues 200-226) encoded by KSAP1 1 orf10. However, the number of repeats of a specific amino acid sequence, PIEPEK, encoded by orf 10 was 12 in KSAP7 and 2 in KSAP11 (Fig. 2b). A search for orf10-like genes in other Silviavirus phages indicated that the number of PIEPEK repeats varies from 2 to 12 (Table 1). However, orf10-like genes of phage $\mathrm{K}$ and Twort belonging to the same subfamily (Twortvirinae) as KSAP7 and KSAP11 but different genera (Kayvirus and Twortvirus, respectively) did not have this repeat sequence (Table 1) [8].

A search using GENETYX-Windows (ver. 13; Genetyx, Tokyo, Japan) also revealed that the 30 -amino-acid N-terminal region of ORF10 is hydrophobic, indicating that it could be a membrane protein or a protein with a signal peptide. Although the PIEPEK repeat region was predicted by a BLASTp search to contain domains for TonB (periplasmic protein, link of inner membrane and outer membrane), IgGblocking protein, and amelogenin (biomineralization), the function of ORF10 in the phage infection process remains unclear at present.

Another variable region was found between $\operatorname{orf} 88$ and orf89. A specific 541-bp insert was found between orf88 and orf89 in KSAP11 only. An additional gene, orf88.1, was present in the inserted region. Orf88.1 encoded a 170-aminoacid sequence identified as a putative tail protein including an Ig-like domain.

Phage KSAP7, which does not carry the orf88.1 gene, was also able to grow in many S. aureus strains (Table S1), so ORF88.1 was considered to be additive but not essential for phage growth. A protein similar to ORF88.1 was also predicted in other phages belonging to the genus Silviavirus and in phages ( $\mathrm{K}$ and Twort) belonging to different genera of the same subfamily (Twortvirinae) (Table 1)[8].

In addition, a single amino acid residue (glutamate) was also predicted to be added at the C-terminus in ORF88 in KSAP11 with insertion of the above sequence.

As there was a 50-bp direct repeat in the 3'region of both orf88 and orf88.1 (Fig. 2b), recombination between these repeat sequences might be related to the insertion/deletion of the sequence according to the Campbell model [18].

Here, we report two new members of the genus Silviavirus that appear to be suitable for phage therapy. A comparison of DNA sequences of members of the genus Silviavirus, including KSAP7 and KSAP11, suggested that phages in this genus may have at least two genomic regions where site-specific DNA rearrangements occur. 


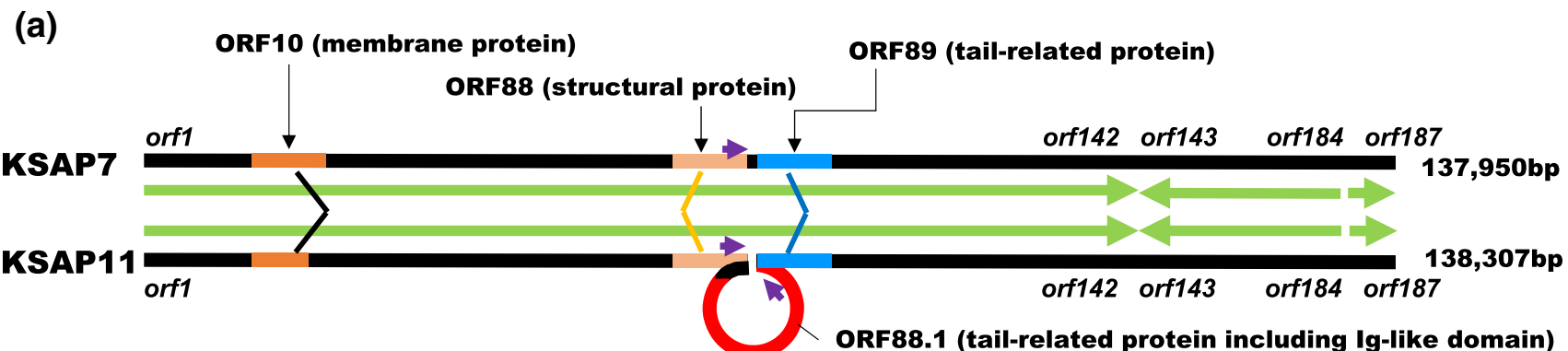

(b)

1: MKRKFSSNEI TITLITIVVA LFIVLITVAF NKYOIAKEDK DRYQKLVEIY OKADDDDGKT

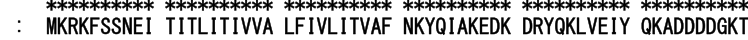

61： KKRYVEKLNR AEEELKKVKE ETNYKGYNDK TEKERDKEDK SVRERIYGND KDKDLVLVNN

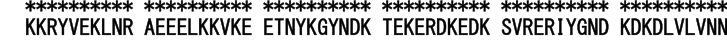

121: KVVVSNEVTR PKIIEDNGVS TVVVPPVVSP VEPPSEPSIP SPTIPNPINP NTILPKPSIP : KVVVSNEVTR PKI IEDNGVS TVVVPPVVSP VEPPSEPSIP SPTIPNPINP NTILPKPSIP

181： TPNPLPPIEP EKPIEPEKPI EPEKPIEPEK PIEPEKPIEP EKPIEPEKPI EPEKPIEPEK

$181: \stackrel{* * * * * * *}{\text { TPNPLP }}$

241: PIEPEKPIEP EKPIEPEKPS SDTTIPLVPL EPSTPVDESN DTNGEG

187 : _-_-_*IEP EKPIEPERPS SDTTIPLVPL EPSTPVDESN DTNGEG

Fig. 2 Complete genome analysis of KSAP7 and KSAP11. a Two variable regions identified in the phage KSAP7 and KSAP11 genomes. Large green arrows indicate the direction of orfs, and small purple arrows indicate a 50-bp direct nucleotide sequence repeat. Insertion/deletion of a 541-bp DNA sequence may occur between orf88 and orf89 by recombination involving 50-bp direct repeats according to the Campbell model. b Variation in the number of PIEPEK repeats in ORF10. Upper row, KSAP7 ORF10; lower row, KSAP11 ORF10

Table 1 Features of two variable regions in the silviavirus genomes

\begin{tabular}{|c|c|c|c|c|c|c|c|}
\hline \multirow[t]{2}{*}{ Phage } & \multicolumn{4}{|c|}{ ORF10-like protein } & \multicolumn{3}{|l|}{ ORF88.1-like protein } \\
\hline & $\begin{array}{l}\text { Related gene } \\
\text { product }\end{array}$ & $\begin{array}{l}\text { Number of } \\
\text { amino acid } \\
\text { residues }\end{array}$ & $\begin{array}{l}\text { Number of } \\
\text { PIEPEK } \\
\text { repeats }\end{array}$ & $\begin{array}{l}\text { Identity to } \\
\text { KSAP7 ORF10 } \\
(\%)^{*}\end{array}$ & Related gene product & $\begin{array}{l}\text { Number of } \\
\text { amino acid } \\
\text { residues }\end{array}$ & $\begin{array}{l}\text { Identity to } \\
\text { KSAP11 ORF88.1 } \\
(\%)^{*}\end{array}$ \\
\hline KSAP7 & ORF10 & 286 & 12 & 100 & Absent & & \\
\hline KSAP11 & ORF10 & 226 & 2 & 79.02 & Present (ORF88.1) & 170 & 100 \\
\hline Remus & Remus_009 & 277 & 8 & 90.2 & Present (Remus_086) & 170 & 97.64 \\
\hline Romulus & Romulus_009 & 277 & 8 & 90.2 & $\begin{array}{l}\text { Present (Romu- } \\
\text { lus_086) }\end{array}$ & 170 & 97.64 \\
\hline SA11 & F422_gp153 & 273 & 9 & 90.72 & $\begin{array}{l}\text { Present (F422_ } \\
\text { gp078) }\end{array}$ & 170 & 95.88 \\
\hline StAP1 & SAP1_035 & 285 & 11 & 94.84 & Present (SAP1_115) & 170 & 95.88 \\
\hline Stau2 & Stau2_17 & 255 & 6 & 84.19 & $\begin{array}{l}\text { Present (BH792_ } \\
\text { gp095) }\end{array}$ & 170 & 95.88 \\
\hline$\phi \mathrm{MR} 003$ & MRS_079 & 237 & 3 & 79.03 & Present (MRS_154) & 170 & 95.88 \\
\hline $\mathrm{K}$ & $\begin{array}{l}\text { CPT_phageK_ } \\
\text { gp179 }\end{array}$ & 397 & 0 & 38.69 & $\begin{array}{l}\text { Present }\left(\mathrm{CPT}_{-}\right. \\
\text {phageK_gp115) }\end{array}$ & 170 & 61.76 \\
\hline Twort & TwortORF029 & 323 & 0 & 39.57 & $\begin{array}{l}\text { Present } \\
\quad \text { (TwortDSMZ_157) }\end{array}$ & 172 & 55.42 \\
\hline
\end{tabular}

* Identity (\%) was calculated using the protein maximum-maching program in GENETYX-Windows Ver.13 
Acknowledgements This study was supported by a Grant-in-Aid for Scientific Research (C) (18K09793) from the Japan Society for the Promotion of Science.

\section{Compliance with ethical standards}

Conflict of interest The authors declare that they have no conflicts of interest.

Open Access This article is licensed under a Creative Commons Attribution 4.0 International License, which permits use, sharing, adaptation, distribution and reproduction in any medium or format, as long as you give appropriate credit to the original author(s) and the source, provide a link to the Creative Commons licence, and indicate if changes were made. The images or other third party material in this article are included in the article's Creative Commons licence, unless indicated otherwise in a credit line to the material. If material is not included in the article's Creative Commons licence and your intended use is not permitted by statutory regulation or exceeds the permitted use, you will need to obtain permission directly from the copyright holder. To view a copy of this licence, visit http://creativecommons.org/licenses/by/4.0/.

\section{References}

1. Lin Derek M, Koskella Britt, Lin Henry C (2017) Phage therapy: an alternative to antibiotics in the age of multi-drug resistance. World J Gastrointest Pharmacol Ther. 8(3):162-173

2. Imanishi I, Uchiyama J, Tsukui T, Hisatsune J, Ide K, Matsuzaki S, Sugai M, Nishifuji K (2019) Therapeutic potential of an endolysin derived from kayvirus s25-3 for staphylococcal impetigo. Viruses. 11(9):E769

3. Oliveira H, Costa AR, Ferreira A, Konstantinides N, Santos SB, Boon M, Noben JP, Lavigne R, Azeredo J (2019) Functional analysis and antivirulence properties of a new depolymerase from a myovirus that infects Acinetobacter baumannii capsule K45. J Virol 93(4):e01163-18

4. Lin H, Paff ML, Molineux IJ, Bull JJ (2018) Antibiotic therapy using phage depolymerases: robustness across a range of conditions. Viruses. 10(11):E622

5. Viertel TM, Ritter K, Horz H-P (2014) Viruses versus bacterianovel approaches to phage therapy as a tool against multidrugresistant pathogens. J Antimicrob Chemother 69:2326-2336

6. Ackermann H-W (1998) Tailed bacteriophages: the order Caudovirales. Adv Virus Res 51:135-201

7. Ackermann H-W (2006) Classification of bacteriophage. In: Calendar R (ed) The bacteriophages, 2nd edn. Oxford University Press, Oxford, pp 8-17
8. Barylski J, Enault F, Dutilh BE, Schuller MBP, Edwards RA, Gillis A, Klumpp J, Knezevic P, Krupovic M, Kuhn JH, Lavigne R, Oksanen HM, Sullivan MB, Jang HB, Simmonds P, Aiewsakun P, Wittmann J, Tolstoy I, Brister JR, Kropinski AM, Adriaenssens EM (2020) Analysis of spounaviruses as a case study for the overdue reclassification of tailed phages. Syst. Biol 69(1):110-123

9. Vandersteegen K, Kropinski AM, Nash JH, Noben JP, Hermans K, Lavigne R (2013) Romulus and Remus, Two phage isolates representing a distinct clade within the Twortlikevirus genus, display suitable properties for phage therapy applications. J. Virol 87(6):3237-3247

10. Takemura-Uchiyama I, Uchiyama J, Kato S, Inoue T, Ujihara T, Ohara N, Daibata M, Matsuzaki S (2013) Evaluating efficacy of bacteriophage therapy against Staphylococcus aureus infections using a silkworm larval infection model. FEMS Microbiol Lett 347(1):52-60

11. Uchiyama J, Rashel M, Maeda Y, Takemura I, Sugihara S, Akechi K, Muraoka A, Wakiguchi H, Matsuzaki S (2008) Isolation and characterization of a novel Enterococcus faecalis phage $\phi \mathrm{EF} 24 \mathrm{C}$ as therapeutic candidate. FEMS Microbiol Lett 278(2):200-206

12. Kim MS, Myung H (2012) Complete genome of Staphylococcus aureus phage SA11. J Virol 86(18): 10232

13. Hsieh SE, Tseng YH, Lo HH, Chen ST, Wu CN (2016) Genomic analysis of Staphylococcus phage Stau2 isolated from medical specimen. Virus Genes 52(1):107-116

14. Senevirathne A, Ghosh K, Roh E, Kim KP (2017) Complete genome sequence analysis of a novel Staphylococcus phage StAP1 and proposal of a new species in the genus Silviavirus. Arch Virol. 62(7):2145-2148

15. Peng C, Hanawa T, Azam AH, LeBlanc C, Ung P, Matsuda T, Onishi H, Miyanaga K, Tanji Y (2019) Silviavirus phage $\phi M R 003$ displays a broad host range against methicillin-resistant Staphylococcus aureus of human origin. Appl Microbiol Biotechnol. 103(18):7751-7765

16. Kumar S, Stecher G, Tamura K (2016) MEGA7: molecular evolutionary genetics analysis version 7.0 for bigger datasets. Mol Biol Evol 33(7):1870-1874

17. Stoddard BL (2014) Homing endonucleases from mobile group I introns: discovery to genome engineering. Mibile DNA 5:7

18. Campbell A (2007) Phage integration and chromosome structure. A personal history. Ann Rev Genet 41:1-11

Publisher's Note Springer Nature remains neutral with regard to jurisdictional claims in published maps and institutional affiliations. 